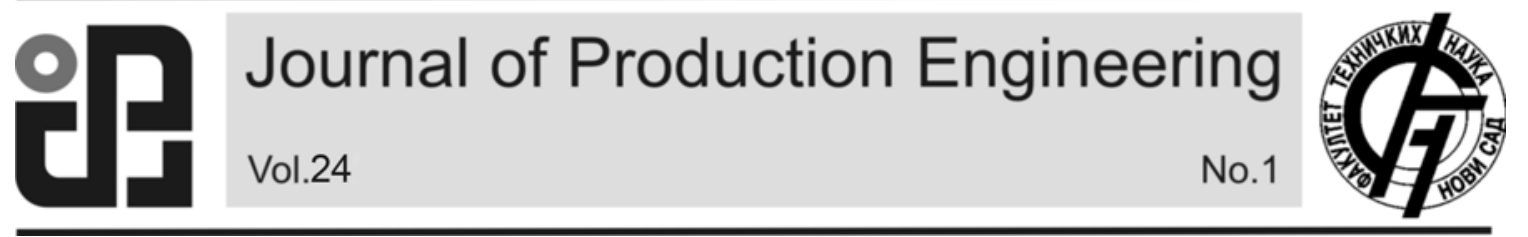

JPE (2021) Vol.24 (1)

Mudabbiruddin, M., Pokorádi, L.

Preliminary Note

\title{
AGING OF TECHNICAL SYSTEMS - LITERATURE REVIEW
}

Received: 21 April 2021 / Accepted: 14 June 2021

\begin{abstract}
The maintenance is one of the most important territories of practical vehicle engineering. For optimal management maintenance decisions one of the most important matter to know momentary technical state of given system. In this paper literature of aging of technical systems is studied briefly. We found 2 major topics. They are maintenance management and mathematical modelling. These and their connections with other matter was widely studied in the field of aging. In this review we comparatively discuses all the methods and their theories. It will be very helpful for other readers to choose any methods to carry out better results.
\end{abstract}

Key words: Aging; maintenance management; mathematical modelling.

Starenje tehničkih sistema - pregled literature. Održavanje je jedno od najvažnijih područja praktičnog inženjerstva vozila. Za optimalne odluke o održavanju menadžmenta jedna od najvažnijih stvari je poznavanje trenutnog tehničkog stanja datog sistema. U ovom radu se ukratko proučava literatura starenja tehničkih sistema. Pronašli smo 2 glavne teme. Oni su upravljanje održavanjem i matematičko modeliranje. Ove $i$ njihove veze sa drugom materijom široko su proučavane na polju starenja. U ovom pregledu uporedno razmatramo sve metode $i$ njihove teorije. Drugim čitaocima će biti od velike koristi da odaberu bilo koje metode za postizanje boljih rezultata. Ključne reči: Starenje; upravljanje održavanjem; matematičko modeliranje.

\section{INTRODUCTION}

Aging can be defined as different type changes is system that occurs due to fatigue failure, affective reason such as erosion and corrosion of machine parts causes increase in wear and tear rate, thermal contraction and expansion, effective increasing load over the capacity with respect to running time is also responsible for aging of machines [15].

The aging of technical system is also depending upon fatigue limit of machines and hence the fatigue limit is also important to consider as per their environmental condition. Change in temperature is the main reason for increase in corrosion due to that any technical structure is being aged. For that premaintenance methods with proper inspection are to be scheduled [23].

In the field of machines, if there are no proper maintenance then it will be big loss for the company by all means. To improve reliability and quality and to reduce the risk, proper maintenance is must. With the help of aging model of the investigated system, it can be maintained properly.

There are two problems which is to be taken into consideration:

1. How to find lifetime reliability of technical system?

2. How to do modelling with effective methods in framed time?

Based on aging data, we can create a mathematical model with the help of linear or non-linear regression models or any mathematical tools which can coordinate with regression model and can develop theoretical measurements which helps to monitor tool condition [18]. Simple linear and multiple linear regression technique is useful and with the use of these, Model can be made. In this paper we will discuss about different kind of methods to calculate aging of technical systems with the help of mathematical model.

In the era of maintenance of technical system there are lots of studies and research is carried out. In this review we comparatively discuses all the methods and their theories. It will be very helpful for other readers to choose any methods to carried out better results.

This review summarizes the following five major topics related to aging of technical systems:

- aging;

- wear \& tear;

- erosion \& corrosion;

- mathematical modelling;

- maintenance management.

The main aim of this paper is studying connection between these topics.

This paper is organized as follows: Section 2 the maintenance management and its connections with other topics will be shown. Section 3 shows the mathematical modelling and its correspondence with other issues. Section 4 presents the connections between mathematical modelling and maintenance management. Finally, Section 5 concludes the article, summarizes the main conclusions of this literature review and proposes some future research directions.

\section{MAINTENANCE MANAGEMENT}

The maintenance impacts the success of industries. Maintenance management is a complex control process the maintenance required to preserve assets at, or repair them to, an acceptable working order. Maintenance management share similar objectives no matter the 
industrial production or service activities.

The relation between maintenance management, mathematical modelling, aging, and wear \& tear shows in figure 1 . respectively.

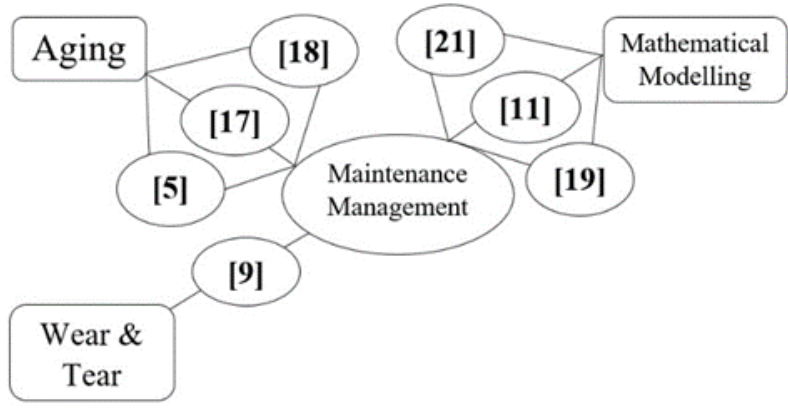

Fig. 1. Relations of Maintenance Management with Other Investigated Topics

\subsection{Maintenance Management and Aging}

Aging is the most important factor in this literature review, we will review all the classified articles according to aging and will illustrate their methodology and results will conclude accordingly. Figure 2. shows the relationship between maintenance management and aging.

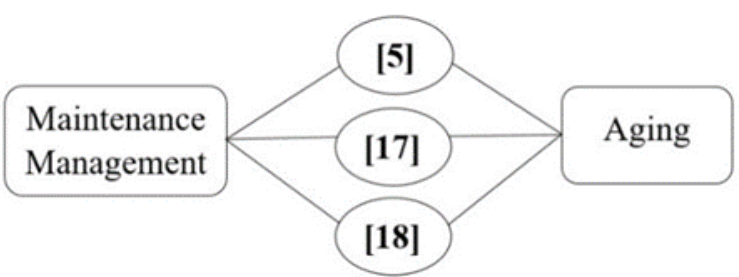

Fig. 2. ConnectionS between Maintenance management and Aging

Bollen studied aging and reliability of power systems. Time-varying failure rates is discussed based on weather for aging of components. Weibull distribution is used to determine failure rate. Maintenance model is made and validate with 5 years. Results shows that weather conditions are to be taken into consideration when reliability analysis is done. Given model shows an increase in interruption frequency when less maintenance is performed [5, 20].

Pérez Ramírez et al. presented a model for life extension of water pumps in oil and gas industry [17]. With the help of virtual age, the model can be applied to the components. Real maintenance data from oil and gas industry are used to estimate the model parameter to obtain virtual age. By changing model parameter, alternatives for the life extension can be studied which helps to find better decision-making model. Using beta factor mode, common cause of failure can be modelled.

Pirc et al. have studied development of cable insulation using Differential Scanning Calorimeter [18]. Their main aim was to confirm the functionality of cable for beyond 40 years. Cable ageing management programming is implemented which uses visual inspection and measurement of environmental parameters. Samples were temperature aged in oven. Infrared thermography camera and temperature meters are used for data collection. Results shows that decrease in oxidation stability of inner insulation. Chlorosulfonated Polyethylene (CSPE) material is used in the insulation protection which shows no changes.

\subsection{Maintenance Management and Wear \& Tear}

The proposed topic is wear and tear. We will discuss briefly wear and tear phenomena in the mentioned articles as shown in figure 3 . Based on wear and tear phenomena articles are classified. The aim of the proposed articles is to find out the wear/tear on machines which helps to find out the life of machines, to reduce the cost and loses and to improve the efficiency of technical systems.

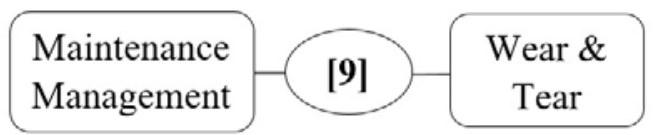

Fig. 3. Connection between Maintenance management and Wear \& Tear

Jantunen et al. focuses on development of wear and failures by managing measurement and their diagnosis. Chemical wear is considered in this theory. Two methods are used to monitor the wear i.e., optical and vibration. Maintenance software sensor (Condition based maintenance) are used which leads to high cost. Bathtub curve is used. With the help of sensor which alarms if any defect found, complicated and hidden surface can be monitored and easily we can find the wear data based on time, load, and wear. Preventive action can be made which results low wear [9].

\section{MATHEMATICAL MODELLING}

For the modern maintenance management it is indispensable to apply the mathematical modelling. The model is a description of the investigated system, or process. In other words: Model is a simplified copy of the real system or process which emphasizes its important characteristics and neglects secondary characters from the point of view of the given investigation.

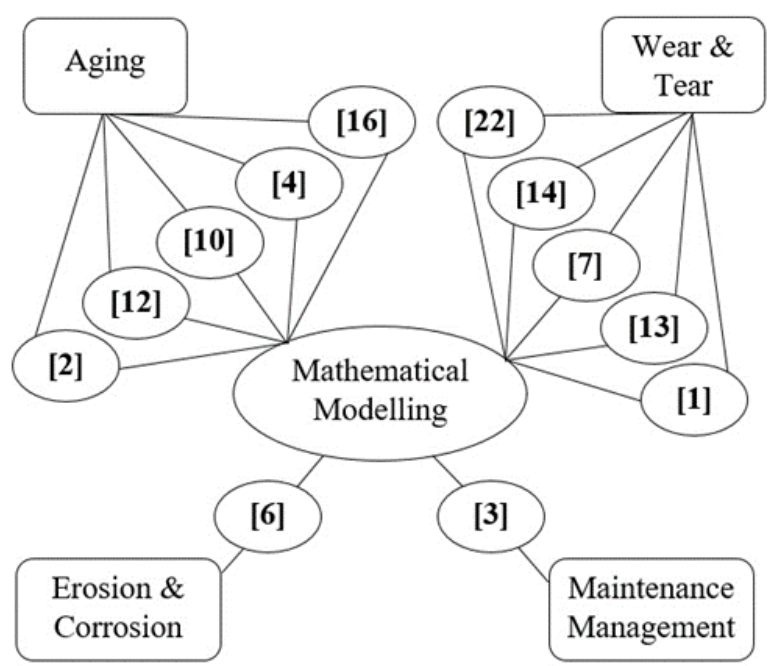

Fig. 4. Relation between Mathematical Modelling and Other Investigated Topics 
In the maintenance management practice the most widespread models are the mathematical ones. The mathematical model is the mathematical equation or system of equations which describes the internal principles of the process occurring on the system from the point of view of the given investigation [19].

The relationship between mathematical modelling with aging is studied and it has a strong connection with each other can be seen in figure 4 .

\subsection{Mathematical Modelling and Aging}

Aging is the basic phenomena which is directly related to material properties and conditions. Whereas mathematical modelling is related to the determination of prediction theory to estimate the aging. In this study five papers presented their theories which connects mathematical modelling and aging as shown in figure 5 .

On the basis of that we can conclude that mathematical modelling is the best method to predict the aging with the help of aging data by means of different methods used by the authors.

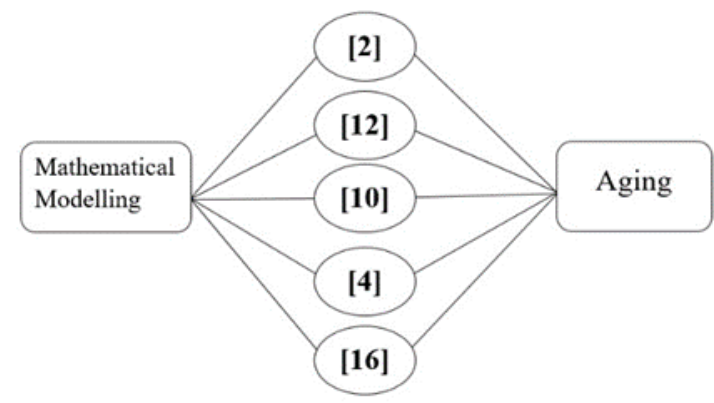

Fig. 5. Relations between Mathematical Modelling and Aging

Al Jed et al. studied aging of Lithium-ion battery cells. A black box modelling approach is used to estimate functional time and their usage condition. Regression mathematical model was used that helps to allow estimation of mentioned aging factor which are residual capacity, internal resistance, peak power, and Open Circuit Voltage (OCV). Multiple linear regression and support vector machine are used in both linear and non-linear models. SVM gave satisfying results for all four aging factors. MLR gave satisfying results only with open circuit voltage. Relationship between OCV and other factors are linear [2].

$\mathrm{Lu}$ et al. presented new aging data analysis method. Arrhenius model and Eyring model are used and then generalize the lifetime under normal level stress condition using accelerated model can reduce aging test time. According to aging data, mathematical model is determined with the help of least square method. With the help of this model using aging test fata, 1000 hours of lifetime index can obtain [12].

Kassi et al. studied aging effect on mineral oil of cooling capacitors in power transformers. Thermal aging test were done. Mathematical approach did on test data which reveals relationship between viscosity and temperature. Finite element method using COMSOL Multiphysics software is used to solve the equation. An axisymmetric thermo fluidic numerical model is present. Results shows that viscosity increases with aging which affecting its physiochemical properties. Up to 500 hours, there is no effect on cooling capacity which increases the risk of degradation of solid insulation, impacts negative on the life of transformer. Life of transformer is directly proportional to life of solid insulation [10].

Arias Velásquez and Jennifer Vanessa Mejía Lara studied bushing failure in power transformer and influence of moisture. They investigated the claim of FDS (Frequency Domain Spectroscopy) method. Using OIP model, SAT (Site Acceptance Test) condition are verified with respect of aging rate, temperature and conductivity for oil and paper. Dielectric tests are done. Theoretical calculation and simulation with test of bushing has been performed. With the help of spectroscopy efficiency are diagnosed. Results shows that FDS can detect insulation degradation and moisture presence which leads to find the root cause of bush failure [4].

Nunes et al. proposed the analyzing method by modelling the magnetic properties which reduces the need of measurements. After that it is to predict the aging, namely properties evolving with time depends upon thermal, magnetic, or mechanical loadings. It used the classical magnetic viscosity theory. The experimental setup is used to measure the hysteresis loops of permanent magnets. Aged model is used based on aging factor and irreversible susceptibility. It is proved that it is the efficient way to estimate the aging of permanent magnets. Aging factor is proportional to the irreversible susceptibility [16].

\subsection{Mathematical Modelling and Wear \& Tear}

Wear and tear are the most important factors which cause aging. Excess pressure leads to wear and tear and due to that quality of tool and product affect simultaneously. Modelling is used to predict the wear and tear rate. With the help of collected data and on the basis of required condition mathematical model is evaluated.

In this study, the five most interesting paper presented their views in connection with modelling and wear tear. Which shows wear and tear is also an important factor to create mathematical model. All the related papers are summarized and presented below in figure 6.

Xiong et al. presented tool wear measurement technology. A 2D model with the help of MATLAB is introduced based on image processing method which tends to increase the level of accuracy. Level set method and CCD camera is used for images. Flank and crater tool wear is taken into consideration. Proposed model is based on $2 \mathrm{D}$ which is not considerable to measure the depth [8, 21, 22].

Medvedev has presented theoretical mathematical method. With the help of pin on disc method and regression equation wear rate is find out. Energy intensity under friction of machine parts is illustrated. Due to this he found the relationship between energy and method of mechanical processing [14].

Eichwald et al. examined production bonding parameters using the Archard and Fleischer wear law. Finite element method is used in copper wire bonding 
process for wear simulation. Results shows that wear is increasing over vertical wire deformation [7].

Luo and Wang used 2D finite element model of sliding wear. Wear of self-lubricant bearing is used as sample. ANSYS (APDL) Program is developed. Wear is calculated by Archard wear theory. Adaptive wear step algorithm is used for better accuracy. Wear in middle region is more as compared to other area. Quasi static process is used for non-linear and dynamic wear problem [13].

Ahmed et al. studied wear behavior of managing steel using direct metal laser. Wear coefficient calculated using pin on disc method than mathematical model is developed to estimate the wear rate. Results based on static optimization shows that sliding speed, distance and normal load affects the wear rate of specimen [1].

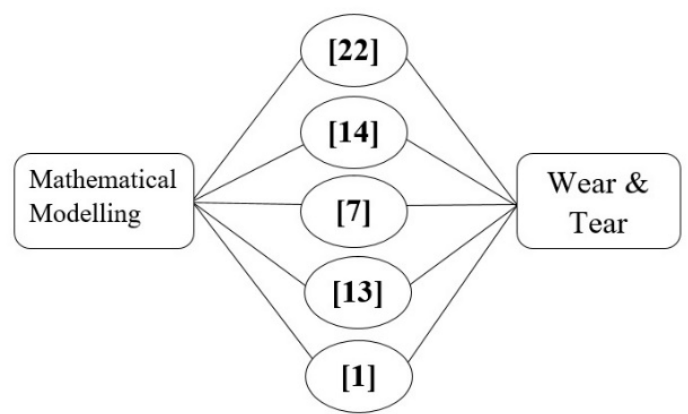

Fig. 6. Connections between Mathematical Modelling and Wear \& Tear

Mohamad Danish Anis presented optimization of centrifugal pumps using in Sanitary Wastewater Treatment Plant (SWTP). Hydraulic model, Operation model, Deterioration model, Optimization model are used. Mathematically computed solutions are applied to models with linear programming. A life cycle cost analysis s done to make accurate predictions. There is time consuming and costly. These models illustrate potential to reduce the life cycle cost and $\mathrm{CO} 2$ emissions. Results shows that they can provide optimal repair schedule for future [3].

\subsection{Mathematical Modelling and Erosion \& Corrosion}

As we all know erosion and corrosion is mostly dependent on surrounding condition. To develop the mathematical model in aspect with erosion and corrosion, data can be evaluated by FEM method.

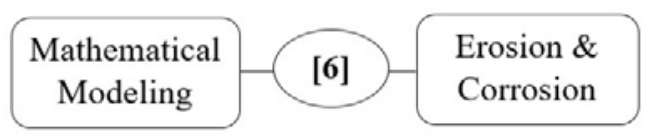

Fig. 7. Connections between Mathematical Modelling and Erosion \& Corrosion

In this study we also found one paper. Figure 7. shows the relationship between modelling and erosion and corrosion which is studied below.

Casesnoves et al. studied erosion and corrosion in power plants. Basic linear, nonlinear optimization technique and finite element method are used in mathematical model. Variables are determined with software, tribology test and made the suitable mathematical model [6].

\section{MAINTENANCE MANAGEMENT AND MATHEMATICAL MODELLING}

There are lots of maintenance management schools. According to schools keep focus on their investigating, which are the next: organizational-, condition-, quality-, reliability-, process and mathematical schools [19]. The mathematical school provides help with mathematical descriptions to decision-making. Pokorádi is a Hungarian representative of this school.

To reduce the failure, maintenance management is used and to predict the failure, mathematical modelling are used wisely. Hence it is clearly stated that modelling in maintenance management is obligatory now a days. We found the relationship between mathematical modelling and maintenance management which is shown in figure 8. Maintenance management involves many factors from cost to the final product in an industry. Based on that model is to be made to evaluate the overall efficiency of an industry.

In this section every failure and its life predicting method is goes through modelling. We covered related research studies in terms of mathematical modelling which are interconnected with all other described important topics. They are shown in figure 3.

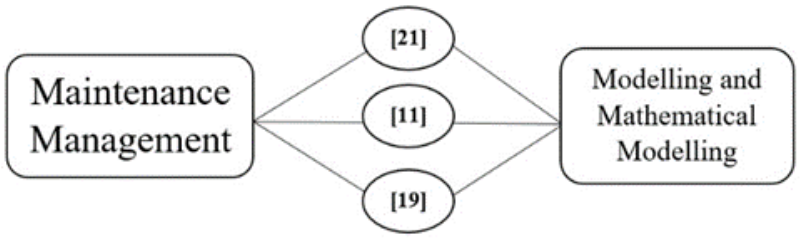

Fig. 8. Connections between Mathematical Modelling and Maintenance Management

Valis et al. studied oil quality which causes wear [21]. Antioxidant wear particles are taken into consideration. Theory of fuzzy logic is used which helps in regression analysis. Fuzzy interference model has been. Results shown that oil filling could be left in a motor at least twice as long.

Khalaf et al. proposed a failure cost mathematical model for medical equipment maintenance. The model is simulated in science lab using real data taken from maintenance history. Regression analysis is done on yearly basis data. Failure models are presented and then corrected using preventive maintenance. Anesthesia machine has no effect on age while doing preventive and corrective maintenance, but preventive maintenance has survival issue [11].

Pokorádi presented mathematical models used for safety management. The paper [18] focuses on the safety requirements for human and environment in today's world of engineering. hence for that mathematical model and safety tool are studied. Safety management in maintenance should be done to avoid any kind of risk and make the system more reliable. 
Reliability parameter in systems with complex interaction are investigated for sensitivity model. Fuzzy methods in safety management are described and focused to make a new fuzzy rule consist of summarized defuzzification based on risk assessment methods.

\section{CONCLUSION FUTURE WORK}

The role of maintenance is very important in any kind of technical system. These maintenance procedures are scheduled as per the aging of system. The aging of required system is predicted with the help of modelling and mathematical modelling.

Aging of technical system is studied briefly. We found 2 major topics which is widely studied in the field of aging. One is maintenance management and second is mathematical modelling. In this study we presented the relation between maintenance management and mathematical modelling can be seen in figure 1 and figure 8. Apart from these 2 topics other factors are also studied which plays an important role like erosion and corrosion, wear and tear. Combining all of them in a manner, short literature review is presented.

In the spirit of these reviewed papers and based on their survey, the authors suggested key issues in their future research work are:

- study different (deterministic - stochastic; crisp soft) mathematical tools generally;

- using statistical analysis and hypothesis testing, to collect data for model-based investigation of ageing of technical systems;

- survey possibilities of use of Markov process theory to analyze maintenance systems and processes;

- work out methodology of new mathematical modelbased decision making methods to support maintenance management.

Due to the objectives, generalizable results are expected to describe the aging processes of technical systems.

\section{REFERENCES}

[1] Ahmed G. M. S, I. A. Badruddin, V. Tirth, A. Algahtani, and M. A. Ali, (2020). Wear resistance of maraging steel developed by direct metal laser sintering. Materials Express, Vol. 10, No. 7, (2020) pp. 1079-1090, ISSN 2158-5857.

[2] Al Jed. H, A. Mieze, J. M. Vinassa, and R. Simon, (2010). Mathematical modeling of aging factors for Li-ion battery cells. IEEE Vehicle Power and Propulsion Conference, France, ISSN 1938-8756, ISBN 9781424482191 pp. 1-4, IEEE, Lille.

[3] Anis M.D. (2018). Identifying a Mathematical Model to Optimize Pump Maintenance Planning Decisions - A Case of Irrigation Asset Management in K.S.A. Condition Monitoring and Diagnosis (CMD, (2018) pp.1-6, ISSN 8535792.

[4] Arias Velásquez R. M. \& J. V. Mejía Lara (2018). Bushing failure in power transformers and the influence of moisture with the spectroscopy test, In: Engineering Failure Analysis 94, Richard Clegg, Cesar R. F. Azevedo, Edward A. Saunders, pp. 300312, ISSN 1350-6307.
[5] Bollen, M. H. J. (2001). Effects of adverse weather and aging on power system reliability. In: IEEE Transactions on Industry Application. pp 452-457, ISSN 1939-9367.

[6] Casesnoves, F.; M. Antonov, and P. Kulu, (2016). Mathematical models for erosion and corrosion in power plants. A review of applicable modelling optimization techniques. 57th International Scientific Conference on Power and Electrical Engineering of Riga Technical University, RTUCON 2016, Latvia, ISBN 9781509037315, pp.1-11, IEEE, Riga.

[7] Eichwald, P. et al., (2016). Micro Wear Modeling in Copper Wire Wedge Bonding. IEEE CPMT Symposium Japan, ICSJ 2016, ISBN 9781509020379, pp.21-24, IEEE, Kyoto.

[8] Hegab H., Hassan M., Rawat S. et al.. (2020). A smart tool wear prediction model in drilling of woven composites. International Journal of Advanced Manufacturing Technology, Vol.110, (2020) pp.2881-2892,ISSN 14333015.

[9] Jantunen, E. et al., (2016). Optimising maintenance: What are the expectations for Cyber Physical Systems. 3rd International Workshop on Emerging Ideas and Trends in Engineering of Cyber-Physical Systems, EITEC 2016. Austria, ISBN 9781509011520, pp.53-58, EITEC, Vienna.

[10] Kassi, K. S. I. Fofana, M. I. Farinas, and C. Volat. (2015). Aging effect on oil cooling capacity of a non-guided disc windings power transformer. IEEE Conference on Electrical Insulation and Dielectric Phenomena (CEIDP), USA, ISSN 00849162, ISBN 9781467374972, pp 804-807,IEEE, Michigan.

[11] Khalaf, A. et.al, (2017). Failure-Cost Mathematical Model for Medical Equipment Maintenance. International Conference on Advances in Biomedical Engineering, ICABME, Lebanon, ISSN 23775696, ISBN 9781538616420, pp1-4, IEEE, Beirut.

[12] Lu, G. et al., (2012). Aging data analysis methods based on short-term aging test. Proceedings of 2012 International Conference on Quality, Reliability, Risk, Maintenance, and Safety Engineering, China, ISBN 9781467307888, pp 905-908, IEEE, Chengdu.

[13]Luo, L. \& Wang X. (2012). Aging data analysis methods based on short-term aging test. Proceedings of 2012 International Conference on Quality, Reliability, Risk, Maintenance, and Safety Engineering, China, ISBN 9781467307888, pp 905908, IEEE, Dalian.

[14] Medvedev. D. M, (2016). Modeling the interrelation of wear resistance of machine parts with conditions of their mechanical processing. Proceedings of 2015 International Conference on Mechanical Engineering, Automation and Control Systems, Russia, ISBN 9781467381147, pp 1-5, IEEE, Tomsk.

[15] Muhr. M, (2008). Aging and Degradation, Their Detection and Monitoring \& Asset Management. Proceedings of the International Symposium on Electrical Insulating Materials, Japan, ISBN 9784886860057, pp 183-186, IEEE, Yokkaichi. 
[16] Nunes, A. S. et al.., (2020). Modeling of the magnetic behavior of permanent magnets including ageing Effects. Journal of Magnetism and Magnetic Materials, Vol.512, October 2020, pp 166930, ISSN 0304-8853.

[17] Pérez Ramírez P. A, Utne. I. B, (2013). Decision support for life extension of technical systems through virtual age modelling. Reliability Engineering and System Safety, Vol.115, March 2013, pp 55-69, ISSN 0951-8320,

[18] Pirc, M. et al.., (2018). Cable aging monitoring with differential scanning calorimetry (DSC) in nuclear power plants. Transactions of Famena, Vol.42, No.1, May 2018, pp 87-98, ISSN 18491391.

[19] Pokorádi, L. (2019). Models in Safety Management. Machine Design, Vol.11, No. 3, pp. 85-94., ISSN 1821-1259.

[20]Ramakumar, R. (2004) System reliability, Eng. Handbook, Second Ed., no. 5, pp. 191-1-191-16, 2004

[21] Valis, D. Zak, L \& Chaloupka, J. (2004) Using oil quality indicators as system technical life characteristics and maintenance optimizers, IEEE International Conference on Industrial Engineering and Engineering Management (IEEM), Singapore, ISSN 2157362X, ISBN 9781467380669, pp 1-5, IEEE.

[22] Xiong, G. Liu, J. and Avila, A. (2011). Cutting Tool Wear Measurement by Using Active Contour Model Based Image Processing, IEEE International Conference on Mechatronics and Automation, ICMA. China, ISSN 2152-7431, ISBN 9781424481149, pp 670-675, IEEE, Beijing.

[23]Zhang, Y. et al.. (2009). Mathematical model and influence of temperature as a factor of metal alloy corrosion, International Association of Computer Science and Information Technology - Spring Conference, IACSIT-SC 2009, Singapore, ISBN 9780769536538, pp 171-173, IEEE.

Authors: Mohammed Mudabbiruddin, prof. dr. László Pokorádi, Óbuda University, Institute of Mechatronics and Vehicle Engineering, Budapest, Hungary, Phone.: +36 1666 5469,

E-mail: mohammed.mudabbir@uni-obuda.hu pokoradi.laszlo@bgk.uni-obuda.hu 